\title{
On Being Stuck: Tapping into the Creative Power of Writer's Block by Laraine Herring. 2016. Shambhala Publications, Boulder, Colorado. US\$16.95. ISBN 978-1-61180-290-0 (Paperback)
}

\author{
Stephen K. Donovan \\ Taxonomy and Systematics Group, Naturalis Biodiversity Center, Postbus 9517, \\ 2300 RA Leiden, The Netherlands; Steve.Donovan@naturalis.nl
}

Received: 4 November 2017; Accepted: 15 November 2017; Published: 20 November 2017

I may be the wrong person to review a book on writer's block. I am very much of the same mind as Silvia [1], who succinctly stated on p. 46 of his book, "Saying that you can't write because of writer's block is merely saying that you can't write because you aren't writing. It's trivial. The cure for writer's block ... is writing". My latest pronouncement on the subject [2] took only two and a half pages and said something similar, albeit at greater length. Yet here is Laraine Herring (such a delicious name) covering the same ground in 173 pages. Silvia and Donovan were obviously economy editions-what is new in the Herring approach?

To be succinct, whereas I would get over not writing by writing, Herring uses a melange of non-writing, meditative techniques including yoga and tai-chi. This is not a direction in which I, personally, would venture, although Herring also preaches the basics such as having a writing schedule and sticking to it. My philosophy is that the more a writer writes, then the more a writer will write. Herring's attitude is substantially different—if you are not writing, go to a place where you can contemplate not writing and shake it off.

Meditation and contemplation apart, Herring has some interesting things to say on the subject of writer's block per se. She does repeat many times that she anticipates the reader to be writing a book/novel, whereas we academics are more likely to be scribbling research papers. Writer's block when writing, say, 5000 to 10,000 words is less disastrous than if your aim is 60,000 to 100,000. Even when I am writing a book or monograph, I subdivide the writing load into numerous smaller sections which eventually fit together; can this not be done when writing a novel? Is there really that much difference? I remain unconvinced.

Yet from p. 1 Herring does seem to side with the angels: “I don't believe in writer's block, per se, but I know very well the feeling of suddenly being stuck in my writing". So, is Herring's use of yoga an equivalent of my standard thinking/brain de-clogging methods, such as going for a walk or changing my location, such as from desk at home to a corner table in a café? We seem to be drawing closer together.

Herring's Foundation Tool Kit (p. 4) of “... practices, prompts, movement activities, playlists ... " sounds like an equivalent to my walks, but one which can be kept in a box under the bed. Some may need movement activities or the right music to scramble out of a writing slump. I understand and must approve. It is the job of the individual to study themselves and know what will work. As Herring so rightly observes, "You don't have to attend an expensive [writers'] workshop or buy another book ... when you get stuck" (p. 14).

I doubt if many academic authors acknowledge the worth of writing practice (Chapter 3, 'Create a Consistent Practice'). I did not when I was younger and would have benefitted. It was only when I had an administrative job, with $10 \%$ research time, that I first planned my writing time with any rigour. I developed a writing pattern of finishing one project per month, even if it was only a short 
note, conference abstract or book review. I kept it simple and kept it quick, and only then took to travelling everywhere with a notebook. I wrote sentences, paragraphs and pages when odd lengths of time opened up. Those clumps of words were written as practice, but always with purpose; I aimed to later massage them into shape and slot them into a typescript in preparation.

Herring rightly emphasizes that the creative process is part of writing (Chapter 4, 'Understand the Type of Block You're Working With). I am willing to recognize that crafting a novel or memoir is a different process from writing an academic research paper, but both are creative, albeit in different ways. Most notably, the author of a research paper that gets 'stuck' while writing has a shorter path to tread in order to return to the right course and, crucially, will be nearer to the finishing line. That is, a 30-page typescript must be easier to complete than 300 pages. The academic author who gets stuck while writing a paper needs to look hard; am I stalled because of me (I do not write often enough to do so easily and at length without needing to 'recharge' along the way) or my subject? Recognizing the reason(s) for stopping writing will suggest its remediation.

Chapter 6, 'Release Perfectionism's Chains', is a hymn that I am delighted to sing. Write as well as you can every time, but you are unlikely to achieve your best work in your first draft. And your best work, after successive drafts and revisions, is still unlikely to be perfect, but it will be your best work. Resist the pursuit of perfection which is commonly a chase for the unattainable. How perfectionists must agonize when, having completed and submitted a paper (possibly a rare event), their reviewers and editors actually have comments and criticisms. For me, it is adequate to write as well as I can and submit; by ignoring the impossible ideal, I maintain a healthy published output. "Perfectionists rarely finish anything because, well, it's not perfect enough yet, and so it holds you hostage" (p. 37).

Part Two, "To Move through a Block" (Chapters 7-30), is a collection of ideas of varying worth to the academic, but different writers will find different sections of use. So, for example, Chapter 7 , "Welcome Your Writing", says the obvious-do not write in the wrong place. Find a right place (you may have two or more) and write there. Herring bubbles with good suggestions. Set realistic goals for each session (Chapter 8) and organize yourself so you have time to write (Chapter 10), rather than manufacturing facile excuses as to why you are not writing. Arrange your writing practice so that it contributes to a product that can be finished (Chapter 14).

Herring tells writers to recognize that research is not writing, even if both tasks rely on the same machine (Chapter 18). "Because many of us use our computers for both research and writing, research can feel deceptively like doing the writing ... it's not writing the book" (p. 89). To write effectively, it is essential to document your study to the end, resisting tangents that may be fun, but which fail to progress your project. Effective academic writing goes from A (start writing) to $\mathrm{Z}$ (publication) by the most direct route, which may show subtle changes between one paper and the next. We may halt in writing a paper, temporarily, while we deal with some other aspect of life, but we do need to be able to slide back into the same writing space at some later date and add the next words. Multiple false starts are never an effective way to finish any writing project; remember, " . . it takes a long time to write a book" (p. 90) or whatever. When you are genuinely stuck, try changing things: find a new place to write; or, if you usually work on a computer, try a pencil and paper (p. 99).

So, in the end, I enjoyed On Being Stuck. Herring writes well and engages the reader. Academics write for a living, yet many have a lackadaisical approach, unfortunately. Those who struggle to write may find help in Herring's book, but not an all-encompassing answer, which the author must determine for their self. We all have different ways to kick-start our writing when the ink dries up; Herring's book has diverse recommendations and approaches to restarting writing, so the chances are that there is something to help you.

Conflicts of Interest: The author declares no conflict of interest. 


\section{References}

1. Silvia, P.J. How to Write a Lot: A Practical Guide to Productive Academic Writing; American Psychological Association: Washington, DC, USA, 2007.

2. Donovan, S.K. Writing for Earth Scientists: 52 Lessons in Academic Publishing; Wiley Blackwell: Chichester, UK, 2017.

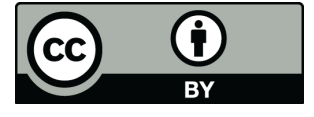

(C) 2017 by the author. Licensee MDPI, Basel, Switzerland. This article is an open access article distributed under the terms and conditions of the Creative Commons Attribution (CC BY) license (http:/ / creativecommons.org/licenses/by/4.0/). 